\title{
Flaviogeranin, a new neuroprotective compound from Streptomyces sp.
}

\author{
Yoichi Hayakawa ${ }^{1}$, Yumi Yamazaki ${ }^{1}$, Maki Kurita ${ }^{1}$, Takashi Kawasaki ${ }^{1}$, Motoki Takagi ${ }^{2}$ and Kazuo Shin-ya ${ }^{3}$
}

The Journal of Antibiotics (2010) 63, 379-380; doi:10.1038/ja.2010.49; published online 19 May 2010

Keywords: flaviogeranin; glutamate toxicity; naphthoquinone; neuroprotective compound; Streptomyces

Cerebral ischemic disorders are one of the main causes of death. In brain ischemia, blood flow disruptions limit the supply of oxygen and glucose to neurons, initiating excitotoxic events. These include activation of glutamate receptors and release of excess glutamate inducing neuron depolarization and significant increase of intracellular calcium, which activates multiple intracellular death pathways. ${ }^{1}$ Accumulation of extracellular glutamate also inhibits cystine-glutamate exchanger, resulting in depletion of the intracellular antioxidant glutathione.,3 Under such conditions, reactive oxygen species are generated and implicated in neuronal cell death. ${ }^{4}$ In this study, microbial metabolites were screened to find neuroprotective agents against glutamate toxicity.

C6 rat glioma cells undergo cell death when exposed to $100 \mathrm{~mm}$ glutamate for $24 \mathrm{~h}$. Thus, they provide a good model for evaluating neuroprotective activity against glutamate toxicity. Our screening using C6 cells resulted in the isolation of a new active compound designated as flaviogeranin (Figure 1) from Streptomyces sp. RAC226.

The producing organism was cultivated in $500 \mathrm{ml}$ Erlenmeyer flasks containing $100 \mathrm{ml}$ of a medium consisting of glucose $(2.5 \%)$, soybean meal $(1.5 \%)$, dry yeast $(0.2 \%)$ and calcium carbonate $(0.4 \%)(\mathrm{pH} 6.2$, before autoclave) on a rotary shaker at $27^{\circ} \mathrm{C}$ for 5 days. The culture broth (2l) was centrifuged and the mycelium was extracted with acetone. After evaporation, the aqueous concentrate was adjusted to pH 3 and extracted with ethyl acetate. The extract was applied to preparative silica gel TLC plates, which was developed with hexaneethyl acetate-triethylamine (150:50:5). The crude material was subjected to HPLC (PEGASIL ODS, Senshu Scientific, Tokyo, Japan) with $87 \%$ methanol and $0.2 \%$ trifluoroacetic acid. The active fraction was further purified by XBridge $\mathrm{C}_{18}$ HPLC (Waters, Milford, MA, USA) with $87 \%$ methanol and $0.2 \%$ triethylamine. The peak fraction was concentrated to dryness to give an orange powder of flaviogeranin $(2.2 \mathrm{mg})$.

The physicochemical properties of flaviogeranin are summarized as follows m.p. $160-165^{\circ} \mathrm{C}$; high-resolution FAB-MS $\mathrm{m} / \mathrm{z} 371.1858$ $\left(\mathrm{MH}^{+}\right.$, calcd for $\left.\mathrm{C}_{22} \mathrm{H}_{27} \mathrm{O}_{5}, 371.1859\right)$; UV $\lambda_{\max }(\varepsilon) 221 \mathrm{~nm}$ (252000),
265 (125000), 307 (64 200) and 429 (29300) in methanol, $220 \mathrm{~nm}$ (250 000), 265 (125000), $307(64000)$ and $429(29300)$ in $0.01 \mathrm{M}$ HCl-methanol, $220 \mathrm{~nm}$ (sh, 246000), 265 (109000), 307 (59500) and 429 (25000) in $0.01 \mathrm{M} \mathrm{NaOH}-$ methanol; and IR (ATR) $v_{\max } 3090$, 3060,1680 and 1630 per $\mathrm{cm}$.

The molecular formula of flaviogeranin was established as $\mathrm{C}_{22} \mathrm{H}_{26} \mathrm{O}_{5}$ by high-resolution FAB-MS. The ${ }^{13} \mathrm{C}$ - and ${ }^{1} \mathrm{H}-\mathrm{NMR}$ data for flaviogeranin are summarized in Table 1 . All one-bond ${ }^{1} \mathrm{H}-{ }^{13} \mathrm{C}$ connectivities were confirmed by an $\mathrm{HMQC}^{5}$ experiment. The $\mathrm{HMBC}^{6}$ spectrum identified a naphthoquinone chromophore as shown in Figure 2. Long-range correlations from a phenolic hydroxyl (5-OH) to C-4a, C-5 and C- 6 and from a singlet methyl $\left(9-\mathrm{H}_{3}\right)$ to C-5, C-6 and C-7 revealed the sequence of four aromatic carbons (C-4a, C-5, C-6 and $\mathrm{C}-7$ ). This substructure was extended to a benzene ring owing to HMBCs from 8-H to C-4a, C-6, C-7 and C-8a. No correlation between $8-\mathrm{H}$ and $\mathrm{C}-5$ arranged them in para positions. A carbonyl carbon $(\mathrm{C}-1)$ coupled with $8-\mathrm{H}$ was attached to $\mathrm{C}-8 \mathrm{a}$. Another carbonyl (C-4) was located at C-4a from intramolecular hydrogen bonding of 5-OH $(\delta 12.69)$ to form a 1,4-naphthoquinone skeleton. Correlations from $3-\mathrm{H}$ to the quinone ring carbons except for $\mathrm{C}-8 \mathrm{a}$ required a para orientation between $3-\mathrm{H}$ and $\mathrm{C}-8 \mathrm{a}$. A methoxy group was substituted at $\mathrm{C}-2$ from their ${ }^{1} \mathrm{H}-{ }^{13} \mathrm{C}$ long-range coupling. A dimethylallyl group was constructed by ${ }^{1} \mathrm{H}-{ }^{13} \mathrm{C}$ long-range correlations from two allylic methyls $\left(8^{\prime}-\mathrm{H}_{3}\right.$ and $\left.10^{\prime}-\mathrm{H}_{3}\right)$ to $\mathrm{C}-6^{\prime}$ and $\mathrm{C}-7^{\prime}$ and a COSY cross peak between $5^{\prime}-\mathrm{H}_{2}$ and $6^{\prime}-\mathrm{H}$ (Figure 2). Another isoprene unit was identified by HMBCs from both $9^{\prime}-\mathrm{H}_{3}$ and $4^{\prime}-\mathrm{H}_{2}$ to C- $2^{\prime}$ and $\mathrm{C}-3^{\prime}$ and a vicinal coupling between $1^{\prime}-\mathrm{H}_{2}$ and $2^{\prime}-\mathrm{H}$. The two units were joined from correlations from $4^{\prime}-\mathrm{H}_{2}$ to C- $5^{\prime}$ and from $5^{\prime}-\mathrm{H}_{2}$ to C-4 ${ }^{\prime}$. An E-configuration for C-2' was deduced from the upfield chemical shift of C-9' $(\delta$ 16.7). A geranyl group thus obtained was connected to 7-O of the naphthoquinone chromophore from a longrange correlation between $1^{\prime}-\mathrm{H}_{2}$ and C-7. These results established the structure of flaviogeranin as 7-geranyloxy-5-hydroxy-2-methoxy-6methyl-1,4-naphtoquinone.

${ }^{1}$ Department of Medicinal and Life Science, Faculty of Pharmaceutical Sciences, Tokyo University of Science, Yamazaki, Noda, Chiba, Japan; ${ }^{2}$ Biomedical Information Research Center, Japan Biological Informatics Consortium, Koto-ku, Tokyo, Japan and ${ }^{3}$ Biomedical Information Research Center, National Institute of Advanced Industrial Science and Technology, Koto-ku, Tokyo, Japan

Correspondence: Professor Y Hayakawa, Faculty of Pharmaceutical Sciences, Tokyo University of Science, 2641 Yamazaki, Noda, Chiba 278-8510, Japan.

E-mail: hykw@rs.noda.tus.ac.jp

Received 26 March 2010; revised 22 April 2010; accepted 23 April 2010; published online 19 May 2010 
<smiles>COC1=CC(=O)c2c(cc(OC/C=C(\C)CCC=C(C)C)c(C)c2O)C1=O</smiles>

Figure 1 Structure of flaviogeranin.

Table $1{ }^{13} \mathrm{C}$ - and ${ }^{1} \mathrm{H}$-NMR data for flaviogeranin in acetone- $d_{6}$

\begin{tabular}{lrc}
\hline No. & \multicolumn{1}{c}{$\delta_{\mathrm{C}}$} & $\delta_{\mathrm{H}}(\mathrm{J}=\mathrm{Hz})$ \\
\hline 1 & 179.7 & \\
2 & 162.0 & \\
3 & 109.8 & $6.14 \mathrm{~s}$ \\
4 & 191.3 & \\
$4 \mathrm{a}$ & 109.3 & \\
5 & 161.3 & \\
6 & 121.3 & \\
7 & 162.8 & $7.19 \mathrm{~s}$ \\
8 & 104.1 & \\
$8 \mathrm{a}$ & 130.9 & $2.113 \mathrm{H} \mathrm{s}$ \\
9 & 8.4 & $5.82 \mathrm{H} \mathrm{d}(6.0)$ \\
$1^{\prime}$ & 66.5 & \\
$2^{\prime}$ & 120.2 & \\
$3^{\prime}$ & 142.4 & $\mathrm{t}(6.0)$ \\
$4^{\prime}$ & 40.2 & $2.102 \mathrm{H} \mathrm{m}$ \\
$5^{\prime}$ & 26.9 & $2.122 \mathrm{H} \mathrm{m}$ \\
$6^{\prime}$ & 124.6 & $5.08 \mathrm{t}(6.0)$ \\
$7^{\prime}$ & 132.1 & \\
$8^{\prime}$ & 25.7 & $1.613 \mathrm{H} \mathrm{s}$ \\
$9^{\prime}$ & 16.7 & $1.823 \mathrm{H} \mathrm{s}$ \\
$10^{\prime}$ & 17.7 & $1.573 \mathrm{H} \mathrm{s}$ \\
$2-\mathrm{OCH} 3$ & 57.1 & $12.63 \mathrm{H} \mathrm{s} \mathrm{s}$ \\
$5-\mathrm{OH}$ & & \\
\hline
\end{tabular}

The neuroprotective activity of flaviogeranin was examined by the 3-(4,5-dimethylthiazol-2-yl)-2,5-diphenyltetrazolium bromide (MTT) method. The relative cell viability was measured as absorbance at

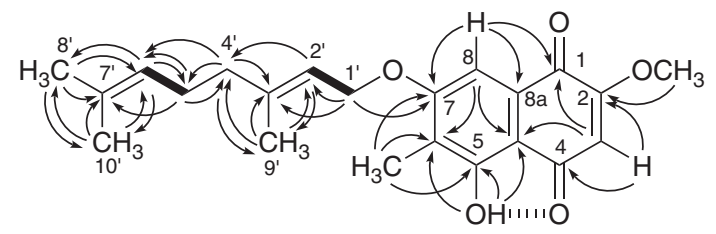

Figure 2 NMR analysis of flaviogeranin. Bold lines indicate ${ }^{1} \mathrm{H}-{ }^{1} \mathrm{H}$ couplings and arrows show ${ }^{1} \mathrm{H}-{ }^{13} \mathrm{C}$ long-range correlations.

$570 \mathrm{~nm}$, after cells were incubated with $0.5 \mathrm{mg} \mathrm{ml}^{-1}$ of MTT for $4 \mathrm{~h}$. Flaviogeranin prevented cell death in C6 cells treated with $100 \mathrm{~mm}$ of glutamate for $24 \mathrm{~h}$ with an $\mathrm{EC}_{50}$ of $8.6 \mathrm{~nm}$. This compound also suppressed cell death in N18-RE-105 rat primary retina-mouse neuroblastoma hybrid cells ${ }^{7,8}$ with an $\mathrm{EC}_{50}$ of $360 \mathrm{nM}$ in the presence of $10 \mathrm{~mm}$ of glutamate. No cytotoxicity against N18-RE-105 cells was observed with flaviogeranin at concentrations up to $2 \mu \mathrm{m}$. Further biological studies are now under way.

\section{ACKNOWLEDGEMENTS}

This work was supported in part by a Grant-in-Aid for Scientific Research, The Ministry of Education, Science, Sports and Culture, Japan. We thank F Hasegawa, Tokyo University of Science, for assistance with mass spectrometry.

1 Taoufik, E. \& Probert, L. Ischemic neuronal damage. Curr. Pharm. Des. 14, 3565-3573 (2008).

2 Murphy, T. H., Miyamoto, M., Sastre, A., Schnaar, R. L. \& Coyle, J. T. Glutamate toxicity in a neuronal cell line involves inhibition of cystine transport leading to oxidative stress. Neuron 2, 1547-1558 (1989).

3 Aoyama, K., Watabe, M. \& Nakaki, T. Regulation of neuronal glutathione synthesis. J. Pharmacol. Sci. 108, 227-238 (2008).

4 Mawatari, K., Yasui, Y., Sugitani, K., Takadera, T. \& Kato, S. Reactive oxygen species involved in the glutamate toxicity of $\mathrm{C} 6$ glioma cells via $\mathrm{XC}^{-}$antiporter system. Neuroscience 73, 201-208 (1996).

5 Summers, M. F., Marzilli, L. G. \& Bax, A. Complete ${ }^{1} \mathrm{H}$ and ${ }^{13} \mathrm{C}$ assignments of coenzyme $\mathrm{B}_{12}$ through the use of new two-dimensional NMR experiments. J. Am. Chem. Soc. 108, 4285-4294 (1986).

6 Bax, A. \& Summers, M. F. ${ }^{1} \mathrm{H}$ and ${ }^{13} \mathrm{C}$ assignments from sensitivity enhanced detection of heteronuclear multiple-bond connectivity by multiple quantum NMR. J. Am. Chem. Soc. 108, 2093-2094 (1986).

7 Malouf, A. T., Schnaar, R. L. \& Coyle, J. T. Characterization of a glutamic acid neurotransmitter binding site on neuroblastoma hybrid cells. J. Biol. Chem. 259, 12756-12762 (1984)

8 Murphy, T. H., Malouf, A. T., Sastre, A., Schnaar, R. L. \& Coyle, J. T. Calcium-dependent glutamate cytotoxicity in a neuronal cell line. Brain Res. 444, 325-332 (1988). 